\title{
LINGUOCULTURAL ASPECT OF PHRASEOLOGICAL UNITS IN AMERICAN ENGLISH
}

Summary. The aim of the article is to study the linguocultural peculiarities of phraseological units in American English. The article enlightens some theoretical grounds of the research, namely the notions of anthropocentric and axiological approach in linguistics, reflecting their role in cognition, perception and imagery of a certain society. The explication of national identity of the American nation in phraseology is considered. It has been revealed that phraseological units contain verbal variant of cultural codes that reflect national picture of the world, demonstrating the peculiarities of national vision of reality. Anthropocentric direction in linguistics in general and phraseology in particular is associated with cognitive activities of the individual and involves axiological component. Axiological aspect defines the system of values of both an individual and the society and is an or-ganic continuation of the anthropocentric one. It is revealed that the most transparent from the point of view of national and cultural features are those phraseological units that contain special linguocultural information: geographic names, landmark names, names of subjects of national culture, representatives of flora and fauna and so on. It is proved that coordination between language and culture is most evident in those phraseological units that contain axiological information and associated with formation of the language picture of the world. Nationally marked idioms reflect the historical development of the ethnos, its traditions and habits, peculiarities of the worldview, etc. Semantic fields where phraseological units serve as a means of expressing of national characteristics of the American nation, namely responsibility and self-reliance, success, privacy, gender equality, patriotism, rivalry have been revealed. Keywords: language picture of the world, anthropocentrism, axiology, linguocultural code, verbalization.

Тимчук О.T. Дрогобицький державний педагогічний університет імені Івана Франка

\section{ЛІНГВОКУЛЬТУРНИЙ АСПЕКТ ФРАЗЕОЛОГІЧНИХ ОДИНИЦЬ АМЕРИКАНСЬКОГО ВАРІАНТА АНГЛІЙСЬКОЇ МОВИ}

\begin{abstract}
Анотація. Мета статті - дослідити сутність лінгвокультурних особливостей фразеологічних одинищь американського варіанта англійської мови у теоретичному аспекті. Розглянуто експлікацію національної ідентичності американської нації у фразеологічному фонді англійської мови. Виявлено, що фразеологічні одиниці містять у собі вербалізовані культурні коди, що відображають національну мовну картину світу, демонструючи особливості національного бачення навколишньої дійсності. Культурний код - категорія універсальна, однак її реалізація на конкретному мовному матеріалі завжди національно забарвлена і відображає систему уявлень і цінностей кожного етносу. Мовна картина світу носія мови фрормуеться під впливом як лінгвістичних (особливості устрою кожної окремо взятої мовної системи), так і екстралінгвістичних чинників (особистий життевий досвід, вік, стать, соціальний статус, освіта, моральні цінності і т. п.). Антропоцентричний напрямок дослідження мови загалом і фрразеології зокрема пов'язаний із когнітивною діяльністю особистості і передбачає залучення аксіологічної складової у дослідження. Аксіологічний аспект визначає систему цінностей як особистості, так і суспільства і є органічним продовженням антропоцентричного. Виявлено, що найбільш прозорими з точки зору національно-культурної специфіки є ті фрразеологічні одинищі, що містять особливу лінгвокультурну інформацію: географрічні назви, прецедентні імена, назви предметів національної культури, представників фрлори і фрауни, тощо. Доведено, що зв'язок між мовою і культурою найнаочніше виявляеться у тих фрразеологічних єдностях, що містять аксіологічну індормащію і пов'язані з формуванням мовної картини світу. Національно марковані фразеологізми відображають історичний розвиток етносу, його традищії і звички, особливості світосприйняття і т. п. Виявлено семантичні поля, в яких фрразеологічні одиниці слугують засобом вираження національних особливостей американського етносу: відповідальність і самоствердження, успішність, індивідуалізм, статева рівність, патріотизм, суперництво.
\end{abstract}

Ключові слова: мовна картина світу, антропоцентризм, аксіологія, лінгвокультурний код, вербалізація.

Gormulation of the problem. Phraseological units are considered to be the most popular material, illustrating the features of native speakers' image of the world. Comparative studies of phraseological units of different languages help to expand the idea of the idiomatics of a certain language and, thus, make a certain contribution to the study of civilization and culture on the whole. By exploring phraseological units, one can trace the entire history of human society: from the birth of traditions and customs to the achievements of science and technology and also to compare the peculiarity of the evolution of two (or more) communities. Phraseological composition of the language involves the transmission of the standards and stereotypes of national culture from generation to generation. Phraseological unit is included in the field of human spiritual semantics, all its meanings are connected with a person, his image of the world and attitude to the environment. Phraseological units form a picture of the world of native speakers, because the results of the cultural experience of the people are concentrated in them. An integrated approach to the study of phraseological units from the point of view of linguistic and extralinguistic factors is considered actual, since phraseological units contain information filled with additional associative and emotional elements.

The aim of the research is to study the theoretical background of linguocultural features of phraseological units in American English. 
Analysis of the investigation. The problems of axiology, associated with the theory of values, were mainly highlighted in the works of philosophers and sociologists. The interest to these problems of linguists and cultural researchers appeared only in the last decade. The theoretical basis of the study is embodied in the works of the scientists in the field of phraseology, linguocultural and linguistic studies, the theory of intercultural communication, cognitive linguistics, ethno-linguistics, sociolinguistics: A. Vezhbitska, V. Kostomarov, O. Kunin, O. Selivanov, V. Teliya and others. The development of questions of linguoaxiology is of great importance for identifying and explaining the specifics of the language picture of the world and the peculiarities of the national mentality, and is associated with the improvement of intercultural communication. The works of M. Arutiunova, L. Bayramova, V. Karasik, Y. Sorokin and others demonstrate their interest to this sphere of linguistics and its particular problems. The scientists research the values of the picture of the world reflected in lexicology, semantics, various conceptospheres of the language, etc. Axiological connotation as a component of connotative complex of lexical units has repeatedly been the subject of research of both Ukrainian and foreign linguists. In particular, this problem is reflected in the works of such linguists as V. Goverdovsky, N. Polyuzhina, V. Teliya, T. Kosmeda, I. Fadeeva and others. Components of the connotation of phraseological units are considered in the works of A. F. Arsentyeva, who also includes imagery to the structure of this connotation.

The study of phraseology based on the principle "a person in the language" has led to the development of a new direction - anthropocentric phraseology. Anthropocentric phraseology, according to some researchers, nowadays is going through a new stage of its development, which can be called interpretic, because "it is the interpretation that is associated now with hopes for a progress in the theory of phraseology, phraseography practice and phraseology didactics" [1, p. 67]. The study of the correlation between linguistic and extralinguistic meanings of phraseological units is an important task of anthropocentric phraseology, as only a portion of mental information is encoded in phraseological meaning, while the other part is represented in the human state of mind by semantic images of extralinguistic nature [1, p. 71].

Presentation of the main material of the research. Anthropocentric approach in linguistic research involves not only defining how a person is represented in the language, but also what a person considers to be valuable to himself or to his society. Axiological aspect of research in linguistics is a natural extension of the anthropocentric one. Anthropocentric direction of modern linguistics development has led to the study of universal linguistic categories that are closely related to human cognitive activity. Evaluation is one of these categories and its uniqueness lies in the ability not only to reflect how valuable the object is for the subject, but also to form public opinion and conception of the world and influence the behaviour of people. Each person is a unique personality, who apprehends and appreciates the laws of nature and social environment in his own way. The individual picture of the world is influenced by many factors, such as a person's life experience, age, gender, social status, education, etc. The most powerful influence on the formation of the human as-sessment scale is the way of life and values of the culture of the society, of which a certain language personality is a part. National and cultural specificity of the people is necessarily expressed in their language. The vocabulary of the language (including its phraseological fund) imposes an imprint on the life of society, its material and spiritual culture. To analyse what values may be expressed by linguistic units and phraseological units in particular is the problem of great linguistic importance in the aspect of axiology. The reorientation of linguistics to the study of anthropocentric language provides theoretical tools adequate to description of this information. In this regard, phraseology is characterized by a strong cultural background, demonstrating the vision of the world and peculiarities of national cultural code. According to M.L. Kovshova, phraseological units are compressed cultural texts: the entire idiomatics of the language is penetrated by verbalized cultural codes [4, p. 218]. Estimation always accompanies epistemological activity of a man and evaluation is a testament to the degree of knowledge of the world and is formed under the influence of such factors as social position of a man, his worldview, level of culture, intelligence, moral development, age, life experience, compliance with the norms and principles of morality. "Knowledge is not limited to the reflection of reality, because a man not only knows but also evaluates the world, evaluates its properties and qualities in terms of their importance to meet his needs" [5, p. 230]. As we know, language is a social phenomenon, so it is inseparably linked to its native speakers and is one of the main forms of expression of national consciousness and reflection of national culture. Awareness of the need for a multifaceted study of the problem of correlation between language and culture has led to the emergence of a new comprehensive field of language science, i. e. linguocultural studies.

Axiological aspect that involves determining what a person considers valuable to himself, those around him and to the society is continuation and significant supplement of anthropocentric approach to the study of linguistic phenomena related to human representation in the language and above all in phraseology.

Therefore, axiological aspect of the research in linguistics is a natural extension of the anthropocentric one.

Language is a social phenomenon, hence it is inseparably connected with its speakers and is one of the main forms of expression of national consciousness and reflection of the national culture. Awareness of the need for multidimensional study of the problem of the relation between language and culture, one of the main in modern lingistics, led to the emergence of a new complex branch of the science of language - linguoculturology, which focuses on the research of human language factor, manifested in his practical life, affecting his philosophy of life, and thus the strategy of discursive practices, which cover all spheres of human presence in the world.

Being an integral part of all registers of the language, phraseology, alongside with the expressive- 
ness and imagery, is characterized by the presence of a thick cultural layer of information and it shows a vision of the world and national culture.

The most transparent from the point of view of national and cultural specifics are phraseological units, which contain special linguocultural information. Their specificity is created in the first place, due to denotative aspects of meanings. These include, for example, those phraseological units which contain the names of subjects of national culture (paddle one's own canoe), flora and fauna (tree the coon), precedent names (California Bible, Jesus society), geographical names (Father Knickerbocker, Connecticut Yankee). However, the fundamental linkage between language and culture manifests itself in those phraseological units that are involved in the formation of the picture of the world of a particular society, conveying important axiological information. In this case, estimation contained in axiological component of the meaning is universal for all members of the society. The American nation is unique due to the fact that it was formed not on the basis of an ethnic group, but on the basis of territorial unity and beliefs. National specifics of phraseology may reflect the history of the people, peculiar traditions, customs, and the character of the nation, originally laid down in its prototype.

The analysis of phraseological units allowed to distinguish several semantic fields, where the mentality of the American people is most noticeable. Thus, the core values of linguoculture of the United States of America are reflected in these dominant features of the national character of the Americans, represented in the phraseological units: self-reliance and responsibility (get off the dime [ODI]); gender equality (Jane Crow [AУФC]); patriotism (the bird of Washington, the Old Glory [AУФC]); privacy (paddle your own canoe [ODI]); activity and hard work (cook with gas [AУФC]); success (to get to first base [AУФC]); competition (in the catbird seat [AУФC]); wisdom (Connecticut Yankee [LDCE]). According to A. A. Jioyeva, the concept of privacy is the key concept in the overall system of English perception and lines like this: geographical distance - body distance - personal (mental) distance - language distance [3, p. 57]. Restraint, caution, practicality and self-esteem are the main features of the English national character, which is very clearly expressed in English phraseology (a hedge between keeps friendship green, if you want a thing well done, do it yourself [AУФC]) and in American phraseology in particular (paddle your own canoe [ODI]).

Conclusion and prospects of further research. The picture of the world of any society necessarily contains an element of self-identification, which is particularly evident in the opposition of members of that society to others outside the group. The American nation is in its own ways unique, because it was not based on ethnicity, but on the basis of territorial unity and unity of beliefs. The American society was formed as the unity of people of different races and nationalities from many countries of the world, which is reflected in the language on the whole and phraseology in particular as the most emotional and expressive part of the language. The analysis of the reflection of the national identity of the American nation in the phraseological fund of American English allowed to distinguish the most peculiar features of the national character, reflected in phraseology: self-reliance and responsibility, gender equality, patriotism, privacy, activity and hard work, success, competition, wisdom, restraint, caution, practicality, self-esteem and competition. The prospects for further research are seen in deepening the development of the theory of axiological approach in linguistics and in phraseology in particular, as well as in the study of phraseology in anthropocentric aspect.

\section{References:}

1. Alefirenko, N.F. (2005). Spornye problemi semantiki [Controversial issues of semantics]. Moskva: Gnozis, 326 p. (in Russian)

2. [AUFS] Anglo-ukrayinskyj frazeologichnyj slovnyk. Blizko 30000 slovospoluchen. 2-ge vid., vipr. [EnglishUkrainian dictionary of idioms]. K.T. Barancev (uklad.). Kyiv: Znannya, 2005. 1056 p.

3. Dzhioeva, A.A. (2006). Anglijskij mentalitet skvoz prizmu yazyka: koncept "Privacy" [English mentality through the prism of the language: the concept of "Privacy"]. Vestnik MGU. Ser. 19. Lingvistika i mezhkulturnaya kommunikaciya. No, 1, pp. 51-57. (in Russian)

4. Kovshova, M.L. (2013). Lingvokulturologicheskij metod vo frazeologii. Kody kultury [Linguoculturological method in phraseology. Culture Codes]. Izd. 2-e. M.: URSS, 456 p. (in Russian)

5. Teliya, V.N. (1996). Russkaya frazeologiya. Semanticheskij, pragmaticheskij i lingvokulturologicheskij aspekty [Russian phraseology. Semantic, pragmatic and linguocultural aspects]. Moskva: Shkola "Yazyki russkoj kultury", 288 p. (in Russian)

6. [LDCE] Longman Dictionary of Contemporary English. London: Pearson Longman, 2009. 2082 p.

7. [ODI] Oxford Dictionary of Idioms / Ed. by J. Siefring. Oxford: OUP, 2005. 340 p.

\section{Список літератури:}

1. Алефиренко Н.Ф. Спорные проблемы семантики. Москва : Гнозис, 2005. 326 с.

2. [АУФС] Англо-український фразеологічний словник. Близько 30000 словосполучень. 2-ге вид., випр. / К.Т. Баранцев (уклад.). Київ : Знання, 2005. 1056 с.

3. Джиоева А.А. Английский менталитет сквозь призму языка: концепт "Рrivacy". Вестник МГУ. Сер. 19. Лингвистика и межкультурная комлуникация. 2006. № 1. С. 51-57.

4. Ковшова М.Л. Лингвокультурологический метод во фразеологии. Коды культуры. Изд. 2-е. Mocква : URSS, 2013. 456 c.

5. Телия В.Н. Русская фразеология. Семантический, прагматический и лингвокультурологический аспекты. Москва : Школа “Языки русской культуры”, 1996. 288 с.

6. [LDCE] Longman Dictionary of Contemporary English. London : Pearson Longman, 2009. 2082 p.

7. [ODI] Oxford Dictionary of Idioms / Ed. by J. Siefring. Oxford : OUP, 2005. 340 p. 